\title{
Recognition Within the Limits of Reason: Remarks on Pippin's Hegel's Practical Philosophy
}

David Ingram

Loyola University Chicago, dingram@luc.edu

Follow this and additional works at: https://ecommons.luc.edu/philosophy_facpubs

Part of the Ethics and Political Philosophy Commons, Metaphysics Commons, Philosophy of

Language Commons, Philosophy of Mind Commons, Political Theory Commons, and the Social Influence and Political Communication Commons

\section{Author Manuscript}

This is a pre-publication author manuscript of the final, published article.

\section{Recommended Citation}

Ingram, D."Recognition Within the Limits of Reason: Remarks on Pippin's Hegel's Practical Philosophy." Inquiry, 53(5), 2010: 470-489.

This Article is brought to you for free and open access by the Faculty Publications and Other Works by Department at Loyola eCommons. It has been accepted for inclusion in Philosophy: Faculty Publications and Other Works by an authorized administrator of Loyola eCommons. For more information, please contact ecommons@luc.edu. c) (i) $\Theta$

This work is licensed under a Creative Commons Attribution-Noncommercial-No Derivative Works 3.0 License. (C) 2010 Taylor \& Francis 


\section{Recognition Within the Limits of Reason: Remarks on Pippin's Hegel's Practical Philosophy}

\section{DAVID INGRAM}

Loyola University Chicago, USA

Since the publication of Charles Taylor's Multiculturalism and the Politics of

Recognition in $1989,{ }^{1}$ the concept of recognition has re-emerged as a central if not dominant category of moral and political philosophy. Taylor's use of Hegel's seminal category to defend group rights aimed at securing legal and public recognition of the distinctive identities of groups resonated with critical theorists such as Jürgen Habermas, Seyla Benhabib, Nancy Fraser, and above all Axel Honneth, who elevated the category of recognition to the most foundational of moral and social categories. ${ }^{2}$ Honneth, for example, drew on the research of developmental psychologists, such as Jessica Benjamin and Donald Winnicott, as well as pragmatists, such as G. H. Mead, all of whom had used the category of recognition to explain how a sense of self emerges from the empathetic identification with primary caretakers. ${ }^{3}$ The accent here on social recognition as a precognitive basis for individuation has been understood, in turn, as a condition for psychological wholeness and well-being or, more radically, as a transcendental condition for the possibility of any relation to the self whatsoever. In the meantime, critics - many of them influenced by poststructuralists currents of thought - have argued that the category of recognition, with its implied identification and reconciliation with the other, designates an impossible and perhaps even undesirable achievement. ${ }^{4}$

Correspondence Address: David Ingram, Department of Philosophy, Loyola University Chicago, 6525 N. Sheridan Rd., Chicago, IL 60660, USA. Email: dingram@luc.edu 
Perhaps they are right. For now I wish only to raise an important challenge to the dominant theories of recognition listed above, insofar as they claim to accurately reflect Hegel's view on the matter. In Hegel's Practical Philosophy (2008), Robert Pippin argues that Hegel's mature concept of recognition is properly understood as an ontological category referring exclusively to what it means to be a free, rational individual, or agent. ${ }^{5}$ I agree with Pippin that recognition for Hegel functions in this capacity. However, I shall argue that conceiving it this way also requires that we conceive it as a political category in the sense described above. Furthermore, while Hegel insists that recognition must be concrete - mediated by actors who hold one another accountable according to institutional norms implicit in their actual social roles - I argue, appealing to Hegel himself, that social crisis impels actors to transcend their roles and adopt abstract points of view more in keeping with philosophical forms of reflection. Such "alienation" - so ardently embraced by postmodernists - need not undermine the possibility of recognition as an ontological category, as Pippin fears, but rather comports with the expressivist theory of action he imputes to Hegel, which describes the socially recognized intentions, rationales, and identities - not to mention, freedom - of actors as unfolding in interminable dialog.

Pippin's argument may be summarized as follows:

1. Action is not adequately identified and explained without appeal to actor's intentions.

2. Actor's intentions are only manifest to him or her through other actors' responses. One cannot be certain of what one has intended and what kind of a 
person one is until after one has acted and one's actions have been judged by others.

3. The social interpretation of actor's intentions unfolds when the actor is challenged to justify his action with reasons that are recognized by others.

4. Such recognition is concrete, since the reasons in questions refer to institutional norms that are accepted by everyone. Recognition between actors implies mutual accountability but not strict equality in social status; nor does it require that actors feel esteemed in the eyes of the other.

5. The agent's successful justification of his action to others is what is properly meant by freedom. Recognition thus functions principally as a minimal condition for freedom, not as a transcendental condition for selfhood or consciousness.

6. Reasons that refer to abstract ideas, purely formal norms, or hypothetical (counterfactual) thought experiments that completely abstract from actual institutional norms have no social basis and therefore cannot serve as grounds for social justification and recognition.

7. Philosophy essentially offers reasons that are abstract, formal, and hypothetical.

8. Therefore philosophy cannot enter into concrete social critique, informing us about what we ought to do; when it goes against this proscription it presents itself as potentially destructive. So philosophers cannot contribute to extending our understanding of ourselves as free agents; viz., they cannot 
enlighten us in a way we might recognize as normatively extending our shared, institutional identities.

In what follows I shall accept premises $1-8$ as positions that are properly attributed to Hegel. Premise 6 strikes me as true only if one assumes that counterfactual forms of reasoning completely abstract from actual institutional norms. Premises 7-8 are likewise conditionally true, so that if it turns out to be the case that social philosophy engages in formal and counterfactual forms of reasoning that do not abstract from actual institutional norms, then they are false. Premise 4 strikes me as partly questionable, since being accorded the status of rational agent and fellow interlocutor is a form of esteem that is constrained by relations of domination. Recognition therefore unavoidably carries with it a political connotation.

Before delving into Pippin's argument in detail, let me first begin by clarifying what he means by saying that recognition is an ontological category. To say that recognition is an ontological category does not imply that it is natural, unchanging, and given all at once with the advent of human life. Insofar as Hegel regards freedom, rationality, and individuality as historical achievements of the human spirit, recognition, too, acquires for him the status of an historical achievement. Therefore, it is not properly understood as a transcendental 
condition for the bare possibility of subjectivity, selfhood, relation to self, or selfconsciousness, insofar as these capabilities can be attributed to children as well as adult human beings prior to acquiring access to skill sets and institutional opportunities associated with rational agency. For Hegel, recognition is simply a necessary condition for the possibility of experiencing oneself as a free, rationally accountable individual (HPP, 185).

Nor is Hegel's notion of recognition a condition of psychic wellness and selfesteem of the sort that figures in the political struggles for recognition discussed by Taylor, Honneth and others. Indeed, Pippin insists that it is senseless to demand as a political goal, or as a matter of right, the kind of recognition Hegel is talking about, for that demand would be meaningless outside of any institution that hadn't already actualized mutual recognition among political agents. Rather, to the extent that Hegel develops what Pippin calls a "recognitive politics" as an alternative to other liberal political rationales of a consequentialist or rights-based nature, such a politics will be first and foremost grounded in institutionally defined social roles, or shared identities grounded in concrete universal norms (HPP, 242, 250, 258, 265). ${ }^{6}$

In sum, no matter how important recognition might be for personal psychological health, basic self-awareness, and political justice between groups, it is not the sort of recognition that Hegel philosophically defends as the telos of fully actualized action. Indeed, according to Pippin, these psychological and political conceptions of recognition are of a different caliber entirely. A group's achieving mutual recognition from other groups regarding the worth of its own members' distinctive racial, gender, or cultural 
identity may be a necessary condition for inter-group dialogue so essential to achieving political justice, understood as equality in the legal and political distribution of social esteem, say, but it is not, in Pippin's reading of Hegel, a necessary condition for enabling the group's members to act in a rational and responsible manner as individual agents. Likewise, achieving emotional bonding and identification with caretakers may be a necessary developmental stage in the process of becoming a fully balanced human being, and it may even well be that absent any such bonding at all infants could never become persons who experience themselves as subjects who live in a meaningful world of objects. ${ }^{7}$ But having been recognized in this precognitive, emotive or empathetic manner of identification is not part of what it means to be a rational actor.

Pippin mentions another reason why conceptions of psychological fulfillmenţ are not central to Hegel's philosophical project. That project consists in presenting and defending a form of argument that is internal to free thought, or reason, itself, understood as radically self-determining, socially embedded, mental life (Geist). This is not to deny that there are natural - and to that extent, partly pre-rational - conditions underlying thought and action. Hegel's idealism does not require that he disregard the physical world and its impact on empirical psychology. However, explanation of human agency cannot be reduced to causal explanation without loss of its proper subject matter, which is reason, or thought, as embodied in concrete action. To the extent that practical philosophy forgets its proper form of idealism and adopts the external, observational and objectifying standpoint of empirical psychology and anthropology, it does a profound injustice to our inner understanding of ourselves as fully free, rationally accountable, agents. 
This explains Pippin's discomfort with respect to left-Hegelian critiques of alienation. Such examples of philosophical anthropology take us away from the Kantian legacy back to a pre-critical Aristotelianism, where rational criticism relies upon an account of human nature, understood as a prior constraint determining volition and thought from without. ${ }^{8}$ But, according to Pippin, to view alienation as a state of unfulfilled nature, as dehumanization, and recognition as restoration of psychic wholeness and humanity, is to think of recognition as something that is natural, always present in some form, however diminished, and thus as an original constraint rather than as a freely accomplished result. This way of conceiving recognition goes against the grain of Hegel's thinking, which holds that the determinations of free action - recognition included - must themselves be the product of action.

\section{II}

Now that we have clarified Pippin's claim that Hegel's concept of recognition is best understood as an ontological presupposition, let's look more closely at his argument purporting to show this to be the case. Pippin's main project is to defend what he regards as Hegel's highly counterintuitive notion of freedom against the apparently intuitive traditional conception. The traditional conception conceives of freedom as a causal power innate within the individual. In the empiricist tradition of Hobbes, Locke and Hume, the will can be said to be free if its decision to pursue this or that desire is unhindered by external impediment. The transcendentalist tradition inaugurated by Kant goes further than this by reasonably insisting that the mere faculty of choice (Willkür) provides a poor foundation for freedom so long as the rational, calculating will remains in 
thrall to pre-rational inclination. But Kant's idea of a spontaneous "uncaused" volitional agency that inhabits some otherworldly noumenal realm while somehow acting in the real world is scarcely philosophically satisfying. How can mere respect for an abstract and empty conception of formal practical reason (the categorical imperative) motivate action, i.e., provide sufficient reason to act this way rather than that, apart from worldly desire?

Hegel's solution to this dilemma involves radically reconceiving the way in which Kant's idea of autonomy as self-legislation is understood. Instead of thinking of autonomy as simply a function of individually exercised practical reasoning, Hegel thinks of it as a dialogical accomplishment in which agents invest their desires in the rational form of validity claims whose reasonableness they then justify to other agents in terms that these other agents recognize and accept.

Hegel's mature defense of this recognitive account of freedom (premises $1-5$ in my reconstruction) proceeds at many levels. In the Phenomenology, his attention is focused on in the dialectical confrontation between the claims and counterclaims of forms of consciousness. As is well known, the section of the Phenomenology in which Hegel discusses the dialectic of self-consciousness (culminating in the relationship between master and servant) disabuses us of any conceit in our own autochthony in its compelling account of why natural self-consciousness cannot be free on its own. This account rearticulates an earlier argument that Fiche had developed in his Grundlage des Naturrechts (1796): to wit, that autonomy first arises when human beings distinguish themselves from animals by transforming their immediate, natural desires into claims, or demands, addressed to others and requiring their recognition. The opportunity to effect this transformation thus depends on challenge from the other. The problem with the 
master-servant relationship that supposedly resolves the existential struggle to the death between persons who demand unreciprocated recognition of their freedom is its incapacity to rise above the fundamental contradiction that recognition cannot be compelled and, indeed, cannot affirm the superior sovereignty of one when given unfreely from another who is deemed to be little more than an object. Although the servant achieves a certain awareness of his own freedom in fearing death, postponing satisfaction of natural need, and dominating nature through labor, neither he nor the lord can achieve subjective certainty of their autonomy and, indeed, cannot be free, because they lack the moral, legal, and ethical preconditions in which they might transform their immediate demands into rationally justifiable validity claims requiring mutual recognition.

This recognitive account of freedom is first developed by Hegel in a later section of the Phenomenology devoted to action as an expression of intention that has significance for others. In the section concluding the chapter on reason, entitled "Individuality which Takes Itself to be Real in and for Itself," we learn "that a person cannot know what he [really] is until he has made himself a reality through action" (para 401). The "purpose" and "matter at hand" in his acting, however, comes to light only as it is expressed and taken up by others, thereby showing that the pure integrity of one's willing is a chimera. Agents may "pretend that their actions and efforts are something for themselves alone in which they have only themselves and their essential nature in mind," but "in doing something, and thus in bringing themselves out into the light of day, they directly contradict by their deed their pretense of wanting to exclude the glare of publicity and participation by all and sundry" (para. 417). 
Finally, in chapter six, subsection (c) entitled "Spirit that is Certain of Itself: Morality," we encounter this dialectic of rudimentary communicative interaction played out on a higher register - the register of social critique, if you will. Dealing not with the abstract determinants of rational action (means and ends) but with the ostensible purity of moral conscience, Hegel emphatically shows that the subjective convictions of moral agents remain essentially incomplete and indeterminate in meaning - lacking in conviction and objective reality - until they are expressed in actions and not only declared in a self-validating way but justified convincingly with reasons before other persons whom the actor recognizes as having the right to judge (paras. 645, 653). Although the forms of consciousness that inhabit this moral world only recognize their own subjective convictions - the result of having seen behind the emptiness of applying a Kantian universal law of reason that transcends any determinate subjective prescription $\bar{q}_{-}$there is a sense in which each asserts his own convictions as normatively binding for everyone else, as if one's inner voice had the same authority as God's command (paras. 655-56). ${ }^{9}$ Acting as if his subjective conviction were universally binding for society, the spectatorjudge (who, for the purposes of this essay, can be compared to the inactive philosophersocial critic or inactive community of political deliberators) accuses the acting agent of hypocrisy by showing that the meaning of the agent's actions is not, contrary to the agent's beliefs, exhausted by the agent's claimed moral intentions, since from the subjective perspective of the judge's convictions, these actions appear to have been morally motivated by such evil, egocentric desires as fame and ambition (para. 665). But in coaxing a confession of wrong from the agent, the hard-hearted judge - who in playing the "beautiful soul" refuses to act for fear of getting her own hands dirty - can scarcely be 
said to claim with convincing conviction that she and not the actor is right, and indeed can also be accused of hypocrisy for betraying a commitment to universal right by

withdrawing into the inner sanctum of her own subjective self-certainty (paras 658, 66365). Forgiveness comes when both actor and judge mutually confess their hypocrisy and recognize their mutual accountability to one another in the course of both simultaneously playing out the dual role of actor and judge. Realizing that deliberative judgments and action-oriented convictions must be backed by reasons that can be communicated to and validated by others heals the wounds of past recrimination, for it enables actor and judge to acknowledge the inextricable connection between subjective conviction and social recognition, acting out of singular self-interest and reconciling that rationale with a social judgment affirming that rationale's universal worth (paras. 667-71).

To paraphrase the moral of this story in a way that Hegel might have accepted had he lived in our post-Wittgensteinian world, we could say that the reasons given by agents for acting and judging do not count as reasons unless they can enter into a language game of challenge and justification in which they are recognized as compelling by others. Any gap between agent's and judge's assessment of what the agent did marks a gap in recognition and, therewith, a gap in the agent's own certainty that what he or she thought she did is what he or she did in fact; and that experience of self-alienation is tantamount to an experience of unfreedom, or absence of self-determination. ${ }^{10}$

Pippin relies on Hegel's mature writings in the Philosophy of Right and in the Encyclopedia to flesh out the implications of this conception of recognitive freedom further. The important points developed in these writings are as follows: If freedom, or taking ownership of one's inclinations, volitions, and intentions - requires transforming 
these subjective events into rationally justifiable validity claims addressed to and recognized by others (as Habermas would say) - then it also requires an intersubjectively recognized framework in which asserting and redeeming individual claims makes sense. That framework is the modern state, understood not merely as government but as shared political understanding firmly anchored in what we today would loosely identify as a liberal and democratic ethos. In other words, it is only within a modern state that objectively recognizes individual freedom and responsibility through legal institutions such as private property, accountable legislative representation, and so on and further grounds these formal institutions in substantive traditions expressing common values, aims, and meanings as well as concrete narrative identities based on intersubjectively recognized roles, that something like genuine individual self-ownership can happen. A further point bears mentioning with regard to this institutional conception of practical reason. Justification will be constrained by - or, to put in the more positive Deleted: Two Deleted: s Deleted: The first is that $\mathrm{j}$ terms favored by Pippin and Hegel, reconciled to - particular social roles and functions; in other words, justification will not be free to methodically detach itself from these roles as if aspiring to become a formal test for determining how any rational speaker or hearer or actor or judge would justify the action in question.

[T] he reflection and deliberation essential to such a subjective dimension (the entertaining of considerations about what one ought to do) are not formalizable, do not involve a method or permanent set of moral rules or a moral law or any sort of moral calculation. One deliberates, as he [Hegel] says, "qua ethical being" (sittliches Wesen). This means that considerations such as "because I am her 
father" or "because that is what a good businessman does," or "you cannot, because that is my property," or "because I am a citizen" simply are practical reasons. They are not initial steps requiring a full deduction of a further claim that, say, one ought always to do as is required of a modern citizen of a Rechtsstaat, all before a subjectively offered reason could really be convincing or successful. The Kantian conception of autonomy and rationality that supports such an intuition is, Hegel claims, a dangerous fantasy (HPP, 274).

The philosopher's temptation to think that there must be some more general, abstract reason supporting the social functional reasons proffered by everyday agents is simply mistaken, for such a reason could not provide a motive for acting that would be more concretely meaningful and prescriptive than the reason institutionally provided. Thus, Habermas's formal pragmatic account of accountability, in which actors also play institutionally unconstrained abstract social roles of speaker and listener apart from their institutionally constrained social roles of, say, doctor and patient, adds nothing to the sorts of specific claims and justifications that a doctor might raise or make with respect to a patient. In justifying the truth of a diagnosis or the rightness of a prescribed regimen of care to the patient the doctor should not have to appeal to a general theory of knowledge or a general moral theory. "Grounded in controlled observation" or "cost-beneficial" or "in accordance with respecting the inherent dignity of the human being" are not reasons that would conceivably justify a concrete judgment taken in abstraction from the particular institutional context. ${ }^{11}$ Radically questioning the truth of science or the appropriateness of medical practice is merely the idle fancy of philosophers who are free 
to adopt wholly abstract and transcendent notions of rational justification, truth, and rightness in their "professional" capacity as purely rational speakers and listeners, unencumbered by the constraints of action.

III

We are now in a position to restate premises 6-8 of Hegel's argument. Pippin's Hegel thinks that the recognitive nature of historically situated rational agency limits the kinds of reasons we can bring to bear in criticizing social institutions, in two respects. According to Pippin's Hegel, we are not entitled, as rational agents, to engage in hypothetical (or counterfactual) arguments, if the form the argument takes is that we could not consent to these institutions as purely rational beings, viz., beings whom we imagine are free to reason without being constrained in their thinking by actual social institutions. ${ }^{12}$ This kind of thought experiment is either vacuous or meaningful in a dangerous way, in that it invites individuals to imagine that they are being impartial when they are in fact imposing their own subjective opinions on the rest of us without so much as making a token gesture on behalf of what the rest of us, who participate in and identify with society and its norms, might think.

Such formal reasoning - with its implicit subjectivism and volunteerism -is the reverse side of that pre-critical, substantive reasoning advanced by Aristotelians. This reasoning, which rejects the formalist appeal to ideal procedure in favor of an intuitive appeal to substantive human capacities, implies a form of moral realism that contradicts the self-legislating nature of rational moral agency. ${ }^{13}$ 
So both formal and substantive criticism, Pippin maintains, would be regarded by Hegel as "external" to the internal, participatory standpoint of rational agents whose justificatory reasons are in some important sense determined (or delimited) by the concrete logical space of the historically finite ethical life (Sittlichkeit) they inhabit. If the justificatory reasons for social critique proffered by contractarian proceduralists and communitarian realists are ruled out as philosophically incoherent and practically "dangerous" (perhaps even "pathological," as Pippin sometimes suggests), it might then seem that Pippin's Hegel could at least allow reasons that criticize the existing ethos immanently, for failing to live up to its underlying telos (or idea). This is true for Hegel, but only with qualification: we cannot understand such reasons as including a claim that individuals are entitled by right to such an ethos.

According to Pippin's Hegel, to demand as a right the actualization of the social conditions underlying one's agency - where such conditions are understood to include the having of rights - is philosophically incoherent, in that it "puts the cart before the horse" (HPP, 257). It makes no sense to claim a right to the presuppositions for claiming a right. Claiming a right to the presuppositions for a claiming a right would lead us down a bottomless pit of demands. Furthermore, the presupposition for claiming rights mutual, unconstrained recognition between persons who hold one another accountable as claimants - is not the sort of thing that can be legally enforced in the way that rights claims must be if they are to count as rights. How does one compel free recognition of a claim without committing a performative contradiction $?^{14}$

Once again, recognition is here seen as an ontological condition, not an object of political struggle undertaken in the name of advancing rights, even though recognition 
itself plainly rests on a political institution incorporating the principle of rights. However, if the ordinary political activity of claiming and justifying rights is not what originally brings the principle of rights into existence in the first place, it might be asked: What is? For Hegel, that answer, of course, is history. It is history - not abstract reason - that justifies this activity; and it is historical, dialectical philosophy - not abstract, counterfactual philosophy - that interprets the logical course of events.

I will examine whether Hegel's historical justification of modern rights - as stated above - is sufficiently dialectical and convincing. Presently I wish to focus on another question: Can Pippin's Hegel consistently exclude abstract, counterfactual reasoning from the recognized play of practical arguments in everyday life? A glance at Pippin's favorable comparison between Hegel's account of concrete rational accountability and that contained in Robert Brandom's Making it Explicit (1994) suggests that it cannot. Brandom's inferentialist account of action posits intersubjectivity as a prior condition of rational agency. Persons hold one another accountable for the commitments that can be inferred from the assertions they make about themselves, others, and the world around them as they interact with others. They are entitled to these commitments only to the extent that others can rely on them in fashioning their own commitments. But Brandom understands the role that communication plays in this process as mainly 
passive; we listen to what others say, observe what they do, and keep score of who is committed to what, being ever vigilant to ferret out conflicting or inconsistent commitments. It is important for me to be able to take over another's commitment, although doing so does not guarantee that what I and that other person understand by that commitment is identical (for each of us inserts that claim into our own unique inferential system of commitments).

Importantly, in Brandom's account of accountability, agreement in understanding is not a full-bodied dialogical achievement of the sort that Pippin attributes to Hegel recognitive account of freedom. On Brandom's account, entitlement to a commitment will depend on consistency with the dominant commitments of one's society. But entitlement in this sense can be determined by simple observation, in the same way that a jury (to cite Habermas) keeps a tally of the points scored by the defendant and the plaintiff in a trial. ${ }^{15}$ Nothing in Brandom's account of entitlement requires that agents actively acquire assent from others by justifying their commitments in the face of direct challenges.

On the other hand, Brandom's commitment to objectivity and truth should incline him to embrace a more robustly dialogical rendering of entitlement. ${ }^{16}$ Achieving objectivity in one's understanding would seem to require testing one's taken-for-granted, subjectively held assumptions in the crucible of dialogical questioning. Furthermore, in asserting our claim to be valid as a matter of objective truth we imply that all persons could be rationally persuaded to accept it. Of course, we cannot assume that any given dialogical exchange of arguments would ever suffice to exhaustively justify the truth of any controversial claim once and for all. Real dialogs are imperfect vehicles for 
conclusively establishing anything, since there are always arguments and points of view that have not been expressed. This has led Habermas to conclude that the idea of truth anticipates a temporally unlimited, viz., fully inclusive, fully free, and fully equal exchange of arguments, what he sometimes refers to as the ideal speech situation. ${ }^{17}$

The implication of this counterfactual ideal notion of dialogical accountability for a recognitive theory of practical reason would seem to be something of the following: Being able to recognize oneself as a fully rational agent depends on recognition from others who relate to one in the dialogical role of "equal interlocutor," but such recognition appears to be, in retrospect, always constrained and temporally incomplete. This accords with Pippin's expressivist view of action: full self-certainty - or full selfownership - of what one is doing depends on what an indefinite number of our fellow interlocutors decides one is doing according to an ever-changing matrix of shared reasons. One's agreement with others in this open-ended process of dialogue would be achievable, if we can be forgiven the expression, only in the fullness of time itself. One's rationale for one's actions may be recognized by others sufficient to permit a modicum of rational self-certainty, but this recognition could not in principle be conclusive, because the ideal preconditions under which it could be met are never given.

\section{V}

Recognition thus appears to be simultaneously factual and counterfactual, given but, in retrospect, not fully so. Because it is not given, it cannot be accomplished within the parameters of finite ethical life, if what one understands by ethical life is time-bound conventional reason. But this conclusion would appear to contradict Hegel's own 
optimistic claims about the fully realized fact of freedom for those participating in the actual institutions that make up the modern state. ${ }^{18}$ What these claims suggest is a complete reconciliation with the modern state as it currently exists, based on unshakeable, viz., final and absolute, reasons about who we are and what we are doing. Such triumphalism has led Honneth and Habermas, for instance, to conclude that Hegel jettisoned the forward-looking, dialogical account of rational justification so strikingly evident in his System of Ethical Life and First Philosophy of Spirit dating back to 180204 for the backward-looking, monological justification present in the Jena Phenomenology of Spirit of 1807. Beginning with this latter work, Hegel putatively defends the absolute incarnation of reason; viz., a final true understanding of ourselves as completely free, by direct appeal to humanity's inevitable, divine-like march to the modern state, behind the backs of agents and quite independently of any dialogical reflection they might have undertaken in enlightening themselves about the imperfect rationality of their social relations. ${ }^{19}$

One therefore suspects that the cunning of reason (List der Vernunft), as Hegel understands the developmental logic underlying history, has its own rationale that far exceeds the reasons of finite acting subjects. To say that this rationale compels submission - on pain of one's being rendered less of a rational agent - suggests that a person could not in principle freely and with reason elect to excuse himself or herself from the prevailing discourses in which he or she is expected to render a rational account. From the standpoint of the radical dissident who questions the presumed freedom, symmetry and consensuality of rational dialog as well as the impartiality of the dominant 
lingua franca, the expectation that he or she give rational account to others might well appear to be an unreasonable - externally imposed - demand.

Now, Pippin might respond to this objection in the following way (HPP, 276). Unless one buys into the implausible view that norms, such as the equality of all persons as bearers of fundamental rights, are facts of reason that have existed in all societies since time immemorial, albeit in partial or distorted, or unclear form, then one is inescapably thrown back onto some grand narrative about historical progress in justifying such norms.

Common knowledge has it that Hegel here commits a kind of genetic fallacy; that he conflates historical necessity, historical possibility, or historical facticity with what is morally right. But the normative ethos that informs our modern understanding of what it means to be rational is not simply the result of a kind of natural fate or metaphysical cunning of reason, as my earlier objection would have it. Following Pippin's reading, Hegel seems to be distinguishing between a developmental logic - the telos of collective action, if you will - and its actual historical realization. Because the telos of collective action can be philosophically discerned only after the fact of its substantial if indeed imperfect actualization, it cannot be what motivates (behind the backs of historical agents) its own realization. Rather, that work is the achievement of historical "agents" or persons who are on the way to becoming agents in the fullest sense of the term.

So the proper way to interpret Hegel's account of the actualization of reason is to stress the role that imperfectly rational social agents play in "freely" constituting, in some unintended way, their own agency across time. The fuller meaning of their action unfolds over time, with the philosopher as interlocutor-judge dialogically questioning and partly contributing to the action's objective meaning. Although, as our discussion of 
moral conscience shows, the philosopher judge cannot be a mere spectator, but must also act and be held accountable to the historical agents whose actions she in turn is judging to recall Marx's famous third thesis on Feuerbach, the educator must be educated by those s/he educates - the philosopher nonetheless acts in a distinctly theoretical; viz., philosophical way. From the retrospective standpoint of the philosopher, history can be interpreted as if it were the culmination of a developmental logic. Following Pippin's reading of Hegel, that logic itself does not pre-exist the actions of historically agents, as though in the beginning that logic, rather than their incompletely actualized, still all-toosubjective intentions causally explained their actions. Rather, we are to understand that incipient intentional actions, with their still undeveloped practices of mutual accountability unintentionally produced, through aggregate effects extending across many generations, something that we today recognize as more fully intentional and rationally individuated activity,

This account of reflective action guiding its own self-actualization has much to

recommend it. But we still need an account of social crisis that explains how such action arises, with all of its progressive, emancipatory potential. Take the example of the dissident who refuses to reason about society in the way that conventional roles would dictate. Hegel is not claiming that one must always account for one's action by appeal to conventional roles, least of all when the rules and terms of the game of rational dialog are suspected of being less rational than what they purport to be. This situation arises in moments of social breakdown, when our ethical identity is shattered and we seem torn 
between conflicting social roles. Hegel's famous gloss on Sophocles' portrayal of the conflict between Creon and Antigone in the Phenomenology illustrates the breakdown of an imperfectly rational ethos in which roles of citizen and family member cannot be harmonized because neither citizen nor family member can give a satisfactory rationale to the other that could justify what he or she is doing. Contrast this breakdown with our modern form of social crisis. In a modern society that has incorporated robust rational accountability all the way down to its core, individuals identify with their multiple social roles less rigidly and dogmatically. Our cultural conflicts don't lead to a wholesale abandonment of rational accountability toward others, even if they produce skepticism and alienation. Such skepticism now appears to be reasonable to the extent that questioning oneself - impelled by challenges from others -is "natural" and finds institutional support. One draws from science in questioning law; or one draws from religion in questioning science. It doesn't matter that the sources of socially recognized reasons aren't strictly universal, so long as there remains at least one overarching institutional support - such as respect for basic human rights - that is. When respect for abstract morality and its concrete embodiment in the concrete civil and political rights of a particular nation diminishes - as is the case with modern forms of ideological fundamentalism - so does respect for modern reason.

So defending Hegel against the charge of conservatism is certainly possible when we realize that abstract moral reflection itself is institutionalized in modern societies for whom social crisis itself has become a permanent, if somewhat tamed, condition. Again, suppose one of the instituted language games in our society is a language of human rights that functions, in part, as a common basis for holding other 
nations rationally accountable and, in part, as a common lingua franca for disputing and resolving moral claims between rival religious and secular groups. Persons who are asked to render an account of their behavior in terms of the reasons afforded by this language game are asked to do so in ways that any rational human being might accept. The universal validity they claim for their reasoning will require that they abstract from the particular ethos they inhabit, or at the very least, hypothetically imagine the possibility of such abstraction. That is to say, they must be able to hypothetically free themselves from the limits of their own ethos and even (perhaps) radically question this ethos.

Now, Hegel might reserve the right of the philosopher to hypothetically question say, the modern enlightenment ethos, as he and generations of critical theorists have done; but like the late Wittgenstein, he probably wouldn't deem this to be an entirely appropriate reflection on the part of everyday citizens. ${ }^{20}$ Note that the problem with this kind of totalizing ethical reflection has nothing to do with foundationalism. Radical questioning doesn't require suspending all our practical judgments at once. Having exorcised the bogeyman of presuppositionless certainty, we can still question our ethos dialectically, from within its circular course of reasoning. Rawls, for example, never denied that his counterfactual contractarian thought experiment, which was aimed at extrapolating general principles of justice for criticizing society, was anything more than a stylized rational reconstruction of commonly shared fixed judgments with respect to the acceptability or unacceptability of particular practices.

Regardless, then, of whether one agrees with Rawls's theory of justice and his peculiar framing of the argument in support of it, the counterfactual reasoning it exhibits is not obviously alien to our modern ethos. Therefore, conceding that average citizens, 
too, can be entitled to a fair share of reasonable philosophical skepticism as their modern birthright, it seems unclear why Hegel would reprimand them for demanding the actualization of that ethos. If the answer is that doing so would enmesh them in some kind of self-referential paradox of the sort that Russell and other analytic logicians were keen on exposing, then that response would surely be one that a dialectician such as Hegel should be wary of giving. If the circular relationship between condition and conditioned, part and whole, subject and object exhibited a good and proper modality of infinite reflection - rather than a bad infinite regress of the sort that foundational reasoning enmeshes us in - then Hegel would have no grounds for complaint.

\section{VII}

So what is Hegel's beef with liberalism's empowerment of individual moral conscience? Hegel does not mean to extinguish the individual moral agent's legitimate right to demand rational justification of what contingently exists. The danger in such a demand - what makes it unreasonable and pathological - is its absolute withdrawal from the public realm of social accountability into the private realm of fanatical self-certainty. Pathological is the self-imposed alienation and self-reification that comes from forgetting or willfully denying, in an act of bad faith, the social preconditions underlying one's own claim to be rationally certain and justified. As noted above, this kind of pathology is not inherent within counterfactual forms of moral reasoning. Even the apparently monological thought experiments deployed by Rawls - and even (somewhat surprisingly) by no less a critic of monological critique as Habermas himself - have a dialogical side, 
as both of these thinkers have emphatically reminded us. ${ }^{21}$ But this fact about psychosocial pathology underscores yet another problem in Pippin's reading of Hegel, which is that recognition cannot be entirely divorced from considerations of esteem and fulfillment that Honneth and others consider integral to that account. Hegel's endearing epithets for pathological withdrawal from society into the inner recesses of self-certainty - "unhappy consciousness," "hypocrisy," "beautiful soul," "fanaticism," and "absolute terror" - suggest that the highway of despair traversed in his phenomenology of spiritual enlightenment goes well beyond the philosophical experience of performative selfcontradiction to encompass a personally felt identity crisis. In fact, freedom recognitively redefined is just another word for being affirmed and esteemed by one's fellow consociates as a fully accountable, responsible agent. What is rationally good and rationally right converge, so that autonomy does not come at the expense of psychological satisfaction and fulfillment.

\section{VIII}

To be sure, there is much wanting in Hegel's account of modernity. Aside from its Eurocentrism, its whiggish, triumphal account of human freedom collides with our post-Foucauldian understanding of how meaning and identity are constituted and constrained by hidden power relations. This understanding brings to bear a distinctly modern skepticism that is not without a trace of that dangerous philosophical abstraction which Hegel so strongly criticized. Indeed I would venture to say that the philosopher today, in the form of the postmodern author, conceptual artist, or editorial columnist, has become a world historical agent, and not - as in the case of Socrates - a mere symptom of
Deleted: Hegel's account of recognition

Deleted: it 
crisis and decline. We moderns have become philosophical actors, reflecting from a distance on the meaning of who we are and what we are doing. Our interminable project of actualizing our free agency in dialogical confrontation with the other condemns us to self-uncertainty in a way that Hegel, perhaps, had but an inkling.

Indeed, it might be argued these days that our existential ethics of freedom as authentic self-ownership is as much anti-subjective as it is subjective, confirming the worst of Hegel's fears. But the counterfactual, aesthetic imaginary behind such efforts of go-it-alone self-affirmation (or go-with-the-flow self-denial) is probably, as Hegel suspected, ontologically rooted in the mundane political ethos wherein we still seek recognition from others, come what may. The delusions of a few Robespierres and Nietzsche-inspired futurists notwithstanding, the revolutionary experiments in fascist and communist social engineering of the modern era are less a testimony to philosophical imagination gone amuck than they are a reflection of a pathological ethos that has failed to break away from the habits of long-standing tradition. Pippin himself concedes this point when discussing the counterfactual thought-experiments proposed by Kantians like Rawls and Habermas. True to Hegel's thinking, these thinkers appealed to historical arguments in showing how the moral intuitions of European-descended peoples were

rational responses to four hundred years of religious and class struggle. Their thought experiments were thus only devices for reconstructively clarifying (rather than justifying) modern substantive ethical intuitions. That said, it was precisely these types of generalizing interpretations and their accompanying counterfactual idealizations that inspired women, workers, and marginalized minorities to imagine otherwise the dominant institutional roles preventing them from being recognized as full-fledged agents in the

Deleted: His contractarian thought experiment was but a device for reconstructively clarifying (rather than justifyin

Deleted: g) these

Deleted: It was counterfactual reasoning of this philosophical kind $t$ 
game of rational deliberation. All of which suggests that the struggle for recognition is

not so far removed from that mutual dialogical questioning that marks recognitive

political life in Pippin's sense of the term.

1 C. Taylor, "The Politics of Recognition," in A. Gutmann (ed.), Multiculturalism: Examining the Politics of Recognition (Princeton: Princeton University Press, 1994), pp. 25-73.

2 See J. Habermas, "From Kant to Hegel and Back Again," in Truth and Justification (Cambridge, MA: MIT, 2003), pp. 190- 202; "Equal Treatment of Cultures and the Limits of Postmodern Liberalism” in Between Naturalism and Religion (Cambridge: Polity Press, 2008), esp. pp. 293-96; "Struggles for Recognition in the Democratic State" in The Inclusion of the Other: Studies in Political Theory (Cambridge, MA: 1998), pp. 203-36; A. Honneth, The Struggle for Recognition: The Moral Grammar of Social Conflicts (Cambridge, MA: 1996); A. Honneth and N. Fraser, Redistribution or Recognition: A Political-Philosophical Exchange (London: Verso, 2003); S. Benhabib, Situating the Self: Gender, Community, and Postmodernism in Contemporary Ethics (London: Routledge, 1992); The Claims of Culture: Equality and Diversity in the Global Era (Princeton: Princeton University Press, 2002),

3 J. Benjamin, The Bonds of Love: Psychoanalysis, Feminism, and the Problem of Power (New York: Pantheon, 1988); D. Winnicott, The Maturational Processes and the Facilitation of the Environment: 
Studies in the Theory of Emotional Development (London: Hogarth Press and the Institute of Psychoanalysis, 1965).

$4 \quad$ See Lois McNay, Against Recognition (London: Polity Press, 2008) and Ralph Shain, "Is Recognition a Zero-Sum Game?" in Telos (Summer 2008), pp. 63-87. The postructuralist attack on recognition is problematic in that it asks us to bracket our shared, normative understanding of ourselves as participants in trustworthy social interactions in which we feel respected and affirmed by others. It may well be that our desire for recognition is a desideratum for reasons mentioned below. But the rejection of recognition as something wholly illusory and ideological is surely misplaced.

$5 \quad$ R. Pippin, Hegel's Practical Philosophy: Rational Agency and Ethical Life (Cambridge: Cambridge University, 2008 - hereafter HPP), p. 259.

${ }^{6}$ See Hegel's remark that "rationality consists in general in the unity and interpenetration of universality and individuality" in Elements of the Philosophy of Right, ed. A. Wood, trans. H.B. Nisbet (Cambridge: Cambridge University Press, 1991 - hereafter PR), p. 276, and his claim that "every individual has his station in life, and he is fully aware of what constitutes a right and honorable course of action" in Introduction to the Lectures on the Philosophy of World History, trans. H. B. Nisbet (Cambridge: Cambridge University Press, 1975 hereafter LPWH), p. 80 (cited in HPP at 259 and 242, respectively). Hegel's point, of course, is not that consequences and rights never count as legitimate political reasons but that they do so only as qualified from the standpoint of some socially recognized role and its proper standpoint.

7 For a discussion concerning the importance of emotional bonding to the achievement of perspective sharing and objective experience, see Michael Tomosello, The Cultural Origins of Human Cognition (Cambridge, MA: Harvard University Press, 1999), Peter Hobson, The Cradle of Thought: Exploring the origins of Thinking (Oxford: Oxford University Press, 2002); and A. Honneth, Reification: A New Look at an Old Idea (Oxford: Oxford University Press, 2008).

${ }^{8}$ Pippin holds that Left-Hegelians (presumably Marx and Feuerbach) see the unfolding of human capacities as a process of labor, rather than as an expansion of the "space of reasons" (HPP, 60-61). This overly naturalistic interpretation of reason (which does not decisively distinguish humans from other primates, for instance) is also implicated in the kind of quasi-Aristotelian teleology that Left-Hegelians ostensibly 
endorse (229). Interestingly, these criticisms parallel those developed by Habermas and second-generation critical theorists, who maintain that the progressive institutionalization of communicative rationality is the primary engine for the reflective development of instrumental reason. See Habermas's critique of Marx in Knowledge and Human Interests (Boston: Beacon Press, 1971), ch. 3. The charge that Marx's LeftHegelianism was only neo-Aristotelian overlooks the extent to which he was also influenced by Rousseau's (and Kant's) notion of freedom, understood as self-legislation. See, for example, his famous reference to Rousseau in Zur Judenfrage.

${ }^{9}$ I thank Ardis Collins for suggesting this interpretation of the relevant passages. For an alternative reading that postulates not a society of moral subjectivists but a society of moral universalists, each of whom identifies the universal with either his own subjective moral conviction or his own abstract political deliberation (freely achieved in tandem with other like-minded souls), see Jay M. Bernstein, "Conscience and Transgression: The Persistence of Misrecognition," Bulletin of the Hegel Society of Great Britain No. 29 (1994), 55-70; and “Confession and Forgiveness: Hegel's poetics of action," in Beyond representation: Philosophy and Poetic Imagination, ed. Richard Eldridge (Cambridge: Cambridge University Press, 1996). „Bernstein interprets the "beautiful Deleted: As Collins notes, soul" as standing in for a "deliberative community" that produces agreement on norms in abstraction from ethical action, while he interprets the conscientious actor as one who acts out of individual conviction without considering how the consequences of his actions impact the community $(1996,36-38)$. Bernstein then compares this dialectic to that contained in Hegel's treatment of Antigone and Creon, and concludes that the Phenomenology effectively ends when both the conscientious actor and the beautiful soul recognize the truth of the "absolute other," viz., the prior context of shared ethical norms that frames their one-sided forms of understanding. For Bernstein, this result rules out 
any good-faith effort to act against or rise above society's norms, either morally or politically. According to Collins' very different reading of this passage, the overcoming of abstract subjectivism and politicization "drained of any content" requires a move beyond morality to religion.

${ }^{10}$ Hegel's reasoning here is certainly not foreign to what some philosophers of criminal law have thought to be necessary for attributing liability. The assignment of criminal liability based solely on subjective criteria is especially tempting in the area of law concerning so-called attempted crime. However, holding someone liable simply on the basis of their intention to commit a crime, in the absence of any outward criminal activity, founders empirically (what evidence there might be is wholly circumstantial or based on subjective testimony of others) and it founders conceptually (the question arises: in respecting the freedom of the would-be malefactor to suddenly repent and change his or her mind before actually committing the crime, how long must we wait before we conclude that the point of no return has been reached in the intending of a not-yetcompleted act?). Holding someone liable on the basis of their character alone, apart from intentions and actions, is equally problematic; by targeting the merely potential criminality of character we are led down a slippery slope toward forms of preventive criminal intervention (detention, interdiction, etc.) that are far removed from our ordinary understanding of the retributive (agency respecting) aim of criminal law and punishment. What is required, instead, is an account of criminal attempts that ties these subjective components taken together (intentions as a reflection of a criminal character; character as a product of intentions, choices, and volitions) to objective actions (past and present) as direct expressions (embodiments) of character/intention. For a theory that defends this 
kind of Hegelian solution, see R.A. Duff, Criminal Attempts (Oxford: Clarendon Press, 1996).

${ }^{11}$ Habermas distinguishes institutionally unbound speech acts that raise universal validity claims to truth, rightness, and sincerity, from institutionally bound speech acts that raise non-generalizable claims whose authority seems attached to particular social roles and functions (see J. Habermas, "What is Universal Pragmatics," in On the Pragmatics of Communication [Cambridge, MA: MIT Press, 1998]). Hegel's claim is that such general appeals to the social roles of a purely rational and unencumbered speaker and listener (or to truth and rightness) in abstraction from specific institutionalized practices are ineffective at best and dangerous at worst. However, Habermas's use of Toulmin's scheme of informal argumentation, which he develops in "Wahrheitstheorien" (reprinted in Vorstudien und Ergänzungen zur Theorie des kommunikativen Handelns [Frankfurt: Suhrkamp, 1984]) is presented as an alternative to deductive forms of reasoning that (in moral philosophy) typically proceed from some general axiom to a particular practical judgment. Nonetheless, Habermas allows that purely rational interlocutors are free to radicalize the demand for justification extending all they way down to the institutionalized medium of speech itself.

${ }^{12}$ Although I argue toward the conclusion of my paper that Rawls cannot be accused of entertaining such a historically transcendent form of criticism, others influenced by Rawls stand so indicted. See, for example, the method of "historical counterfactualizing" developed by Anita Silvers in criticizing discrimination against the disabled and Thomas Pogge's critique of this method. S. Anita, "Formal Justice," in A. Silvers, D. Wasserman, and M. B. Mahowald (eds.), Disability, Difference, Discrimination: Perspectives on Justice in Bio-Ethics and Public Policy (Lanham, Md.: Rowman and Littlefield, 1998), pp. 32, 74, 129; and T.

Pogge, "Justice for People with Disabilities: The Semi-Consequentialist Approach,” in L. P. Francis and A Silvers (eds.), Americans with Disabilities: Exploring Implications of the Law for Individuals and Institutions (New York: Routledge, 2000), pp. 34-53 (esp. 38-42).

13 'Without a possible Aristotelian appeal to the realization of natural capacities in order to establish when one is really acting in practically rational ways (realizing one's natural potential as a rational animal) and without an appeal to a formal criterion of genuinely rational self-determination, this turns out to be the only criterion left: one is an agent in being recognized as, responded to as, an agent; one can be so recognized if 
the justifying norms appealed to in the practice of treating each other as agents can actually function within that community as justifying,, can be offered and accepted (recognized) as justifying” (HPP, 198-99)

${ }^{14}$ This argument, to be sure, plays on an essential connection between rights and claims, and between moral rights and fully (objectively) actualized legal claims. This Hegelian way of framing the category of right would be disputed by Kantians of a certain sort, who would regard rights, ideally speaking, as practical aspirations, or desiderata, to be striven for, which in fact happens to be the way in which human rights are affirmed in the preamble to the Universal Declaration of Human Rights.

${ }^{15}$ J. Habermas, Truth and Justification (Cambridge, MA: MIT Press), p 163.

${ }^{16}$ For Brandom it is reason as socially instituted norm that factually obliges persons to think a certain way, not reason as a counterfactual regulative ideal that directs them to criticize established ways of thinking as such (Truth and Justification, p. 140). In this respect, as Cristina Lafont argues, it is not always clear whether, for Brandom, objectivity really is (as he says) a structural presupposition of language use that forces speakers to adopt an autonomous standpoint critical of any de facto social consensus or whether it is simply the outcome of deferring to such an "authoritative" consensus as a matter of social necessity. As Brandom himself remarks in his reply to Habermas:

The acknowledgement of the existence of conceptually structured facts to which our practices (according to us) answer ... is not meant to have any explanatory value except what can be cashed out in terms of the deontic and social-perspectival articulation of our discursive practices [and so] . . . it is not intended to explain so much as the possibility of that articulation -rather the other way around [(“Facts, Norms, and Normative Facts: A Reply to Habermas," European Journal of Philosophy 8 [2000], p. 360)]

Merging rationality, objectivity, normativity, and truth into a factually preexisting social perspective, Brandom abandons his Kantian transcendentalism in favor of Hegelian idealism. His belief that "factstating talk is explained in normative terms and normative facts emerge as one kind of fact among others" thus commits him to both conceptual and moral realism, a position that Habermas strongly rejects (Making it Explicit: Reasoning, Representing, and Discursive Commitment [Cambridge, MA: Harvard University Press, 1994], p. 625; Habermas, Truth and Justification, p. 168). See C. Lafont, "Is Objectivity 
Perspectival? Reflexions on Brandom's and Habermas's Pragmatist Conceptions of Objectivity,” in Habermas and Pragmatism, ed._M. Aboulafia, M. Bookman, and C. Kemp (New York: Routledge, 2002), pp. 185-209; and my Habermas: Introduction and Analysis (Ithaca, NY: Cornell University Press), Appendix C.

${ }^{17} \mathrm{TJ}, 248$.

${ }^{18}$ The exception to this optimistic claim would be the property-less and unemployed poor, what Hegel calls "the rabble" (Pöbel), that occupy the unincorporated margins of Hegel's market-driven civil society.

${ }^{19}$ For early statements of this position, see J. Habermas, “Labor and Interaction: Remarks on Hegel's Jena Philosophy of Mind," in J. Habermas, Theory and Practice (Boston, Beacon press, 1973), p. 167; and J. Habermas, Knowledge and Human Interests, chs 1 and 2. For later versions of the same see J. Habermas, The Philosophical Discourse of Modernity: Twelve Lectures (Cambridge, MA: MIT Press, 1987), pp. 3942; Truth and Justification, pp. 202-211. The locus classicus of this argument in Honneth's writings is contained in The Struggle for Recognition, pp. 59-63.

${ }^{20}$ Pippin concludes chapter 9 of HPP with the provocative claim that "Marx was right about Hegel. . . The point of philosophy for Hegel is to comprehend the world, not to change it, and this for a simple reason Marx never properly understood: it can't“ (HPP, 272) Pippin later clarifies this remark by adding "[the] objection [that a functional, role-based reason must be justified further by a theoretical, philosophical reason] would again (as in the discussion in chapter 9) confuse the philosophical level at which something like the theory of objective spirit, the phenomenological justification of the Absolute standpoint operates and 'lived' experience 'on the ground' (HPP, 279).

${ }^{21}$ As Rawls made very clear in his discussion of philosophical deliberation as an attempt at reaching "wide reflective equilibrium," the method of Kantian constructivism he uses in order to elaborate the formal device of an original position involves bringing into dialogue fixed, lay moral judgments as well as more reflective and theoretical expert judgments. For Habermas use of counterfactual thought experiments modeled on ideal speech situations, see his discussion of ideological consensus and pseudo compromise in Legitimation Crisis (Boston: Beacon Press, 1975) and, more recently, his critique of positive (enhancing) forms of genetic engineering in The Future of Human Nature (Cambridge: Polity Press, 2003). 